\title{
International Financial Institutions and International Public Goods: Operational Implications for the World Bank
}

Ravi Kanbur

No. 19, December 2002 
UNITED NATIONS CONFERENCE ON

TRADE AND DEVELOPMENT
CENTER FOR INTERNATIONAL DEVELOPMENT

HARVARD UNIVERSITY

\section{G-24 Discussion Paper Series}

Research papers for the Intergovernmental Group of Twenty-Four on International Monetary Affairs

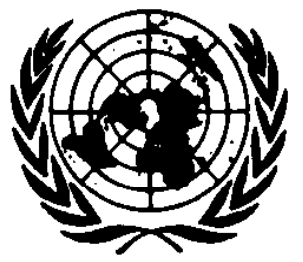

UNITED NATIONS

New York and Geneva, December 2002 


\section{Note}

Symbols of United Nations documents are composed of capital letters combined with figures. Mention of such a symbol indicates a reference to a United Nations document.

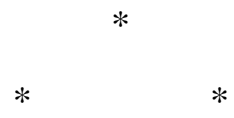

The views expressed in this Series are those of the authors and do not necessarily reflect the views of the UNCTAD secretariat. The designations employed and the presentation of the material do not imply the expression of any opinion whatsoever on the part of the Secretariat of the United Nations concerning the legal status of any country, territory, city or area, or of its authorities, or concerning the delimitation of its frontiers or boundaries.

Material in this publication may be freely quoted; acknowledgement, however, is requested (including reference to the document number). It would be appreciated if a copy of the publication containing the quotation were sent to the Publications Assistant, Macroeconomic and Development Policies Branch, Division on Globalization and Development Strategies, UNCTAD, Palais des Nations, CH-1211 Geneva 10.

UNCTAD/GDS/MDPB/G24/19

UNITED NATIONS PUBLICATION

Copyright (C) United Nations, 2002 All rights reserved 


\section{PREFACE}

The G-24 Discussion Paper Series is a collection of research papers prepared under the UNCTAD Project of Technical Support to the Intergovernmental Group of Twenty-Four on International Monetary Affairs (G-24). The G-24 was established in 1971 with a view to increasing the analytical capacity and the negotiating strength of the developing countries in discussions and negotiations in the international financial institutions. The G-24 is the only formal developing-country grouping within the IMF and the World Bank. Its meetings are open to all developing countries.

The G-24 Project, which is administered by UNCTAD's Macroeconomic and Development Policies Branch, aims at enhancing the understanding of policy makers in developing countries of the complex issues in the international monetary and financial system, and at raising awareness outside developing countries of the need to introduce a development dimension into the discussion of international financial and institutional reform.

The research carried out under the project is coordinated by Professor Dani Rodrik, John F. Kennedy School of Government, Harvard University. The research papers are discussed among experts and policy makers at the meetings of the G-24 Technical Group, and provide inputs to the meetings of the G-24 Ministers and Deputies in their preparations for negotiations and discussions in the framework of the IMF's International Monetary and Financial Committee (formerly Interim Committee) and the Joint IMF/ IBRD Development Committee, as well as in other forums. Previously, the research papers for the G-24 were published by UNCTAD in the collection International Monetary and Financial Issues for the 1990s. Between 1992 and 1999 more than 80 papers were published in 11 volumes of this collection, covering a wide range of monetary and financial issues of major interest to developing countries. Since the beginning of 2000 the studies are published jointly by UNCTAD and the Center for International Development at Harvard University in the G-24 Discussion Paper Series.

The Project of Technical Support to the G-24 receives generous financial support from the International Development Research Centre of Canada and the Government of Denmark, as well as contributions from the countries participating in the meetings of the G-24. 


\section{INTERNATIONAL FINANCIAL INSTITUTIONS AND INTERNATIONAL PUBLIC GOODS: OPERATIONAL IMPLICATIONS FOR THE WORLD BANK}

\section{Ravi Kanbur}

Cornell University

G-24 Discussion Paper No. 19

December 2002 


\begin{abstract}
The global International Financial Institutions (IFIs) increasingly justify their operations in terms of the provision of International Public Goods (IPGs). This is partly because there appears to be support among the rich countries of the North for expenditures on these IPGs, in contrast to the "aid fatigue" that afflicts the channelling of country specific assistance. But do the IFIs necessarily have to be involved in the provision of IPGs? If they do, what are the terms and conditions of that engagement? How does current practice compare to the ideal? And what reforms are needed to move us closer to the ideal? These are the questions that this paper attempts to ask, in the framework of the theory of International Public Goods, and in light of the practice of International Financial Institutions, the World Bank in particular. For the World Bank, a series of specific operational and resource reallocation implications are drawn from the reasoning.
\end{abstract}


Table of contents

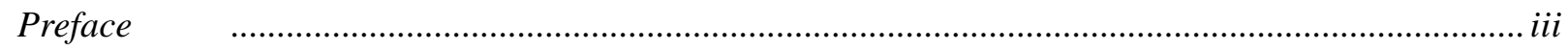

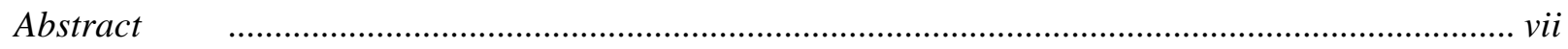

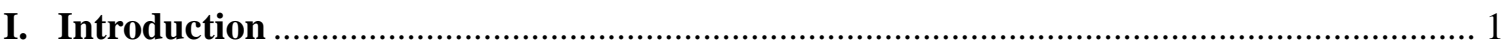

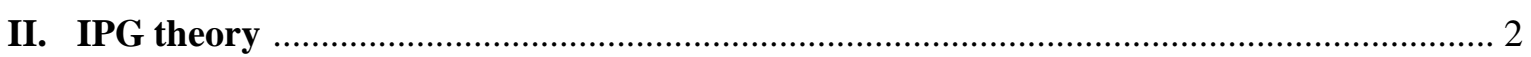

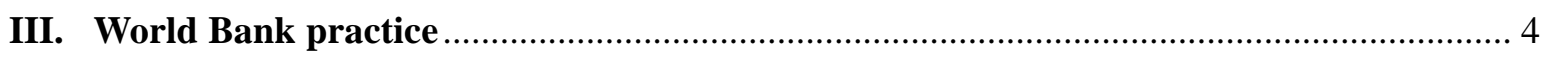

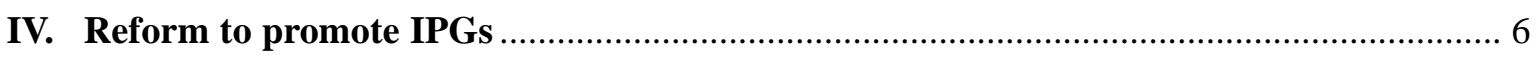

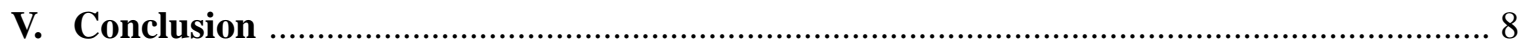

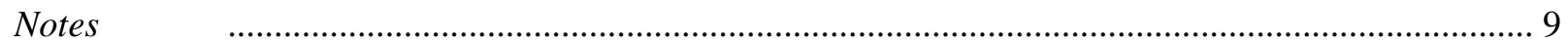

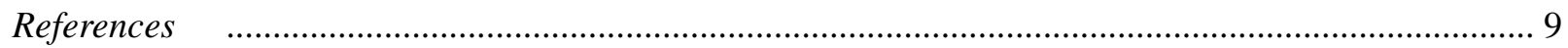




\title{
INTERNATIONAL FINANCIAL INSTITUTIONS AND INTERNATIONAL PUBLIC GOODS: OPERATIONAL IMPLICATIONS FOR THE WORLD BANK ${ }^{1}$
}

\author{
Ravi Kanbur*
}

\section{Introduction}

When people talk of the International Financial Institutions (IFIs), they mean the two Bretton Woods institutions, the International Monetary Fund and the World Bank. Of course, strictly speaking, any multilateral organization with financial operations is an IFI - for example, the regional multilateral banks, regional monetary authorities, some agencies of the United Nations Organization that disburse funding, etc. However, in practice, by IFIs is meant the two global IFIs - the Fund and the Bank. In recent years there has been growing discussion of the role of these institutions in the provision of International Public Goods (IPGs). An aid fatigued public in the rich North, beset by its own internal budgetary problems (for example, the looming social security crisis of an ageing population) and convinced by tales of waste and corruption in aid flows, has grown weary and wary of conventional countryspecific development assistance. In contrast, the notion of IPGs seems attractive to Northern publics - at least their representatives have adopted the IPG refrain in international fora. ${ }^{2}$

But what exactly is an IPG? Given the "aura" that the term seems to have developed, there is clearly an incentive to justify any activity by any agency as an IPG, and aid agencies have not been shy in doing this. At its most general level, development in poor countries is being argued to be an IPG, and hence an argument for continuing conventional aid - disenchantment with which turned the Northern public to IPGs in the first place. On the other hand, highly specific activities like research into vaccines for tropical diseases are also being labelled as the provision of an international public good. If we are not careful, everything will be labelled an IPG, and the concept will lose not only its analytical cutting power, but also its capacity to mobilize Northern resources.

This paper begins by carefully defining IPGs and characterizing their key dimensions (section II). It argues that the concept is subtle and multifaceted, and that in practice there are many different types of IPGs. The mechanisms for provision of these IPGs need to be equally subtle and multifaceted. The IFIs have not been slow off the mark in claiming the mantle of "IPG providers", but the theory of IPGs provides a framework in which to evaluate the claims of the IFIs for resources in the name of IPGs. The paper discusses World Bank practice for specific IPGs (section III), and then considers reforms to better articulate the comparative advantage of the

\footnotetext{
* Paper prepared for the G-24 Technical Group meeting, Beirut, 1-2 March 2002. The paper was also presented at the fifth annual conference of the Centre for the Study of Globalisation and Regionalisation, University of Warwick, 15-17 March 2002. I am grateful to participants at these meetings for their helpful comments.
} 
Bank with the requirements of IPG provision (section IV). The paper concludes (section V) with an outline of areas for further research and analysis.

\section{IPG theory}

As noted above, there is an understandable tendency to fit almost any IFI activity under the IPG umbrella - for example, financial support for vaccine research, in-house economic research on development, capacity building for research in developing countries, collation and dissemination of research, convening international summits on global pollution, developing international trading mechanisms for national pollution permits, multicountry environmental and water preservation projects, raising money from financial markets at lower cost, disseminating and evaluating information on economic and financial conditions in individual countries, developing and monitoring of banking standards, coordinating aid flows from disparate donors, etc.

It is important at the outset to clarify terms and set up a clear framework for identifying IPGs and their key characteristics. ${ }^{3}$ The technical definition of a pure public good is a commodity or activity whose benefits are non-rival and non-excludable. By non-rival is meant that one entity benefiting from it does not diminish the benefit to another entity. By non-excludable is meant that no entity can in fact be denied the benefit. An international public good is one where the entities in question are conceptualized as nations rather than individuals. There are two important points to be made with regard to these two criteria. First, although they help sharp conceptualization, in most practical cases they will only be met partially. Second, while rivalry can be characterized as a property given by technology, excludability is man made.

IPGs relate very closely to spillover effects or externalities between countries, and it is worth clarifying the concept of such international externalities. Consider a collection of nation states that have jurisdictional authority and control over different policy instruments within their own boundaries. However, there are spillover effects of events and policies in one country on other countries, near and far. Civil war in one country sends refugees into near neighbours. Carbon dioxide emissions from one country affect all countries through their impact on global climate. Water use in one country lowers the available water supply for others who share the same water table. Infectious diseases incubated in one place spread to another. Financial contagion, as the name suggests, spreads from country to country; lack of confidence in one country's financial future may unfairly taint other countries in a peer group. Activities that mitigate negative externalities and promote positive ones then satisfy the criteria defining IPGs.

All of the above are examples of cross-border externalities, spillovers that are not mediated by competitive markets. Certain key features of these spillovers will be relevant for our discussion of IPGs and IFIs. The first feature to highlight is the spread of the spillover - what sorts of countries are involved at the two ends of the spillover? It is useful to distinguish between (i) spillovers across developing countries only and (ii) spillovers that include both developing and developed countries. The next feature to consider is the direction of the spillover - is it unidirectional or does the spillover go both ways? Characterization of this is a subtle and intricate matter, and is not independent of the particular circumstances of time and place. The standard example of a multidirectional spillover currently is air pollution, where developed and developing countries are inflicting spillovers on each other. Farm protection policies in North America and the European Union, which create a surplus and depress world prices, are a unidirectional spillover from developed to developing countries. Infectious diseases are in principle multidirectional but in the specific conditions of today the issue is framed as a unidirectional one - poor infectious disease control in developing countries leading (though travel) to spread in developed countries.

Perhaps the most famous example of a unidirectional spillover, at least as it is portrayed in much of the current discussion, is development itself. This argument is being used with increasing force by donor agencies in general, and the IFIs in particular, to justify maintenance and increase of official development assistance. But there are at least two caveats that must be registered. The first is a certain unease with the "there's something in it for us" line of argument bolstering the case for development assistance in the face of an aid-fatigued public. While recognizing that this seems to be working at the moment, at least if statements of politicians are anything to go by, it can be argued that this undermines the more solid moral basis for assistance based on a common humanity and alleviating suffering. 
The second caveat is perhaps more pertinent for the discussion in this paper, and is in any case relevant to the critique noted above. This is that the whole argument rests on the assumption that the transfer in question actually makes the recipient better off. The theoretical literature in international economics is replete with analyses showing how the paradox of an immiserizing transfer can occur. Indeed, one can theoretically get a situation where the transfer makes the donor better off and the recipient worse off - and many NGOs have argued that this is what the aid system, bilateral and multilateral, actually does. The evidence on the efficacy of aid in promoting development is decidedly mixed and, before the IFIs and other agencies are allowed to use the "development is good for developed countries too" argument, they should be subjected to the scrutiny of whether aid is actually good for development. ${ }^{4}$

This paper will not elaborate further on the "development and poverty reduction in poor countries is an IPG" argument. In other words, it will not deal any further with the generalized unidirectional externality from lack of development in poor countries to the well being of rich countries (and other poor countries). Rather, it will focus on more specific activities that (i) although taking place primarily in developed countries, imply a unidirectional positive externality to several developing countries simultaneously, (ii) coordinate multidirectional externalities among groups of developing countries and (iii) benefit developed and developing countries simultaneously, the benefits in all cases being non-rival and non-excludable.

A leading example of the first type of public good is basic research, on tropical agriculture or medicine or even, some would argue, on the development process itself. Examples of the second category of public goods are regional or sub-regional level agreements on transport or water. Finally, global mechanisms to control carbon dioxide emissions, or financial contagion, are example of the third type of public good.

In the case of multidirectional spillovers, whether between developing countries or between developed and developing countries, the central issue is one of coordination failure - each country ignores the negative consequences of its actions on others. All countries could be better off if they took this into account and coordinated their actions. In this case it is the coordination mechanism that is the IPG. Once coordination is in place, countries as a whole benefit, and it is not easy to exclude any one country from this pool of benefit (otherwise why would it want to coordinate?). However, very many different types of coordination are possible, which determine not only the total gains but also the division of these gains. There is thus a range of possible IPGs each with different consequences for different countries.

This last point leads to a very important consideration. Coordination mechanisms may satisfy the technical definition of an International Public Good, but it is important to analyse the distribution of benefits from the coordination - in particular, how are they divided between developing and developed countries? To the extent that the benefits are very unevenly divided against developing countries, what we might have is not so much an IPG as a cartel of developed countries pursuing their own interests. This distinction between an IPG and an international cartel is well worth bearing in mind as we move to a discussion of IFI practice.

The final theoretical consideration ${ }^{5}$ follows from the principle of subsidiarity. This says that all other things being equal, the coordination mechanism must be as close as possible to the jurisdictions being coordinated. Under this rubric, there is a priori no strong argument for a global institution to coordinate the water rights problems of three countries in Africa - rather, it should be an institution as close to the three countries as possible. Economies of scale may suggest a regional level institution to deal with coordination issues between countries in that region - but it is unlikely that they will suggest a global level institution, capable of tackling coordination problems across any group of countries anywhere in the world. Going against this argument is one on economies of scope - that IPG issues in a particular sector (for example, health) could best be combined under a single institution (like the World Health Organization). In practice we may end up with a combination of regional and technical institutions to handle coordination problems within developing countries. ${ }^{6}$ But the claims of a global institution to do all jobs should be treated sceptically. 


\section{World Bank practice}

How does the actual practice of the IFIs compare to the theory of IPGs? How much of what they do can be faithfully characterized as IPGs? The Bank and the Fund are of course complex entities with multifaceted operations in scores of countries and many sectors. They are also controlled primarily by the developed countries, especially by the Group of 7. It will be important to bear this political fact in mind and also to be clear which parts of their operations are being discussed e.g. financial versus research, country specific versus multi-country, etc.) and the criteria for evaluation. The bulk of the operations of the two institutions are country specific in nature and this is unlikely to change in the future.

In this paper we focus on the World Bank. Of its administrative budget of around $\$ 1.4$ billion in fiscal year 2001, about half went directly to support country operations ("Regions"). ${ }^{7}$ If we take away the "overhead" expenditure of administration, corporate management etc., the share of country operations is even higher. This therefore raises two questions. First, to what extent can their country specific operations take on the mantle of international public goods? Second, is there a case for a shift to more of their operations being multi-country in nature, and what would this entail? Under multi-country activities, research and dissemination of research (the budget headings of Development Economics and World Bank Institute) account, for around \$100 million of the total administrative budget. The Development Grant Facility, from which a range of global activities is funded in the form of grants, was around $\$ 150$ million in fiscal year 2001. "Networks" account for almost $\$ 120$ million - it is not clear how much of this allocation is for multi-country activities and how much for supporting country operations, but if we allocate 1 in 8 (roughly, the ratio of research and dissemination to research, dissemination and country operations) of this to multi-country activities, we get $\$ 265$ million ( $\$ 100$ million $+\$ 150$ million $+\$ 15$ million) as the allocation of the administrative budget to this category, compared to $\$ 805$ million ( $\$ 700$ million $+\$ 105$ million) to country specific activities. ${ }^{8}$

It is important to realize that any evaluation of the Bank will stand and fall, for many years to come, by the efficacy of its country specific operations. Let us focus, however, on the non-country specific operations. We start from IPGs for small groups of developing countries and work our way up to global
IPGs. What is striking is that multi-country operations across small groups of developing countries facing cross-border externalities are few and far between. To the extent that they exist, they are generally outside the normal realm of Bank instruments, relying on grants from the Bank's net income, rather than loans from IBRD or IDA. The hugely successful River Blindness project is often produced as an example where the Bank supplied an IPG in which (in concert with other donors) a multi-country project was put into place to counter a vector borne disease - a classic negative externality across geographically adjacent countries, mitigating which benefited these countries in a manner that was at least partly nonrival and non-excludable. ${ }^{9}$

But there are at least two questions that arise, in light of the theoretical discussion in the previous section. First, does the Bank necessarily have to be involved in such IPGs? The principle of subsidiarity suggests that it should be regional institutions that should prima facie have the responsibility for these activities. Even if it can be argued that at the time of the project regional institutions in Africa were not strong enough to take over this task, and even if they are not strong enough now, should we not be aiming for a time when they will be capable of supplying such localized IPGs? Second, how, if at all, can the Bank's standard loan instruments be used in the supply of such public goods? To the extent that they cannot, this surely implies a move in the direction of more grant financing from the Bank as a whole. These questions will be taken up in the next section.

Staying with multi-country coordination, let us move to the case where the coordination required is across developing and developed countries - in other words, a truly global coordination mechanism, the supply of which would undoubtedly count as the supply of an IPG. The Bank is involved in a number of these types of exercises. The global coordination (jointly with the IMF) of debt relief for the poorest countries (the HIPC initiative) is a leading example. It is clear that even for a single debtor country with many creditors there is a major coordination problem in debt relief, since it is in the interest of every creditor to be repaid at the expense of the other creditors. Such coordination mechanisms exist for commercial debt (London Club) and official bilateral debt (Paris Club), but there needs to be a mechanism for coordination across these, as well as of course for multilateral debt itself. Some of the debt issues are quite intricate - for example, the Soviet era debt owed to Russia by African countries, while Russia is itself a debtor to Western nations. 
The case for coordination is strong, but not without questions. Should the Bank be involved at all or should this be left to the IMF? How can either the Bank (or the IMF) be a legitimate coordinator between creditors and debtors when its own debt is at stake?

A second leading example of coordination across developing and developed countries would be the Bank's work in the environment, especially air pollution. Global coordination problems on the use of the seas, on fishing disputes, etc. are dealt with by specialized agencies of the United Nations and various trade organizations, and the Bank does not have a major role. However, for the case of carbon dioxide emissions or ozone depletion the Bank has taken a lead role in conjunction with United Nations agencies such as UNDP and UNEP. The Global Environmental Facility (GEF), for example, was incubated in the Bank but it is now a separate entity, with the Bank listed as an implementing agency, through its regular country operations in countries that participate in GEF projects. This shows another aspect of practice that is of interest. Global coordination will often require country specific projects. To the extent that the Bank's country programmes purposively finance such projects (for example, the Aquatic Biodiversity Conservation project in Bangladesh as a part of the overall objective of global biodiversity conservation) they are part of the supply of IPGs. But this raises yet more questions. What is the trade off between resources for such projects and resources for national development pure and simple? And is it better to use loan or grant instruments for such projects?

Consider now a non-rival, non-excludable and unidirectional positive externality from activities primarily in the developed countries, or in the IFIs, to developing countries as a whole. One example would be generalized lifting of trade barriers, or immigration restrictions against developing countries by developed ones. But the more commonly discussed examples are basic research - for example, into tropical agriculture, tropical diseases, or into the development process itself.

Rather like the River Blindness project, the work of the Consultative Group on International Agricultural Research (CGIAR) is often used by the Bank as an example of an IPG that it is instrumental in helping to supply. Despite the usual problems of an ageing institution, most evaluations of CGIAR generally applaud its achievements in helping to increase agricultural yields in developing countries as a whole. Indeed they call on it to do more, in light of the slowdown in yield growth that has been experienced in the last fifteen years. There is a strong argument for increased financial support of the CGIAR, subject to the usual caveats of institutional reform. By extension, there is strong argument for the Bank to increase its support, which is in the form of grants from its net income. But notice an interesting point. Whatever the Bank's initial role in getting CGIAR off the ground (it can be argued that Foundations such as Rockefeller played an even more crucial incubating role), its current contribution is essentially as a financier (through its Development Grant Facility) rather than provider of substantive input (for example, based on its country operations). This raises again a question on the link between the Bank's role as an IPG provider and its bread and butter country-specific operations.

Similar to the Bank's contribution to the CGIAR, its contribution to various proposed funds for research into diseases prevalent in developing countries satisfies the criteria for helping the supply of an IPG. Basic research that leads to an antimalaria vaccine, for example, could benefit poor countries enormously. While this benefit will of course depend on the specifics of how the vaccine is disseminated, the output of the research itself is non-rival, and furthermore non-excludable provided the right institutional framework is in place that does not create private property rights in its findings. As is well known, the development community faces a difficult trade-off between using the private sector's efficiency in pursuing research goals, and giving private property rights on the outcomes as an incentive, since the benefits would not then be non-excludable. There is the added issue that vaccines or treatments for the diseases of poor people may not be profitable enough. One way to square these various circles is the well discussed device of the Vaccine Purchase Fund, which would act as an incentive to the private sector to do basic research on poor country diseases and then, effectively, make the findings available (at a price). From the point of view of developing countries, the Vaccine Purchase Fund is indeed an IPG, a positive unidirectional externality from the Fund to the countries as a whole.

But once again the question arises - is there anything other than the Bank's financing in the final product of the IPG? In the case of the Vaccine Purchase Fund (rather like in the case of the HIPC fund), it is clear that the Bank's "convening role" has been important, that (along with a small number of individuals and foundations) it was able to nurture the 
basic idea and then expand it out to other partners to the point where it could become operational. This convening and incubating role will be discussed again in the next section.

As a final example of World Bank practice in the supply of IPGs, let us consider its role in producing research on the development process itself. The World Bank, in particular, projects itself as the "Knowledge Bank", and sees its role as a synthesizer of country-specific development experience for the benefit of all countries - an IPG. While the Fund does not project itself quite so aggressively in this mode, it offers the general experience of its staff in a range of countries to policy makers from specific countries, and it also has a large research department. Taking the World Bank specifically, there are two major issues of interest. First is the actual mechanism through which the vast amount of information generated by its operations is synthesized - much is made of the role of new information technology in this process. But secondly there is the issue of how and in what framework the synthesis takes place.

Leaving to one side complex technical and institutional issues of managing knowledge flow, the central issue is that frameworks for understanding and interpreting information and knowledge in the development process are contested. In this context, the Bank can take an open stance of allowing a range of issues to be debated and discussed, with dissenting voices invited and given their proper place, or it can present a particular synthesis and stand behind it to the exclusion of other perspectives. In practice the outcome is somewhere in the middle, with a definite stance on some policy issues (for example capital account liberalization till a few years ago, and trade liberalization now), which reflect and are reflected in country specific operations, but a more open stance on others (for example, on reducing gender discrimination).

Is Bank (and Fund) research an IPG? It is clearly non-rival, in the sense that once the output of the Bank's research goes on to its comprehensive website, access by one person anywhere in the world does not diminish access for another. And the Bank does a very good job in wide dissemination of its findings. It is also non-excludable in the sense that anyone who wishes to have access to the Bank's research can in principle do so. But this is a case where satisfying these technical criteria is not enough we have to look deeper into the consequences of making this research available widely. The consequences depend upon whether the research is believed, and by whom. To the extent that there is a perception, and perception is what matters, that the research is blinkered and dedicated to showing particular results, it will not have a general impact. In this context, effective mechanisms of collecting, organizing and disseminating information through electronic means can only deepen suspicion. The recent discussion of civil society's deep reservations on the Development Gateway is a case in point. ${ }^{10}$

The central question is whether research in institutions like the Bank, who have to take stances and views on policy in their operations, can ever command wide enough trust to be an IPG. This in no way is to impugn the motives of the many fine individuals who do research in these institutions. But they do face constraints, and this is entirely to be expected in an operational organization. The point is not whether there should or should not be a research organization in an operational institution any such institution will need a group dedicated to specific analysis and to interacting with outside analysis. The point rather, is whether IFI research can claim the mantle of an IPG, and thence the aura and the resources that flow from it in the current climate favouring IPGs. Our conclusion on this is a sceptical one, at least when there is a widespread perception that the research is in service of a particular line or policy stance to the exclusion of others. This is perhaps more likely in social science research where, unlike research in the natural sciences, much of the terrain is contested and there is no uniform, unifying framework in which research and its findings can be assessed.

\section{Reform to promote IPGs}

Almost by definition, IPGs will tend to be undersupplied in the world. And this undersupply will often adversely affect developing countries. The World Bank is engaged in a wide variety of activities whose direct (and sometimes indirect) objective is to supply various types of IPGs. Indeed, it (and other international agencies) is using this fact of IPGrelated activities to argue for continued support in a climate where conventional development assistance is out of favour. Before this argument is accepted, it is worth asking whether there are reforms that could make the Bank better at supplying IPGs. The theory of IPGs in section II and the review of some examples of World Bank practice in section III suggest some useful directions. 
Let us start with the (reasonable) assumption that over the next ten to fifteen years the World Bank will essentially remain an organization the bulk of whose operations are country specific projects and programmes. As noted earlier, we do not consider here the argument, increasingly stridently made, that since development itself is an IPG, the Bank's (and other agencies') country programmes should be supported as IPGs. Suffice it to say that the argument hinges on the efficacy of these country programmes in promoting development, and the debate on that will continue. What is important for us here, however, is that the culture of the institution, and the bulk of its detailed knowledge and experience, is and will continue to come from its country operations. Reform of the Bank to promote the supply of IPGs will have to take this basic fact on board, and weave a pragmatic path between current reality and the ideal suggested by the theory of IPGs.

Recalling the discussion of spillovers between adjacent developing countries in section II, a coordination mechanism requires simultaneous actions by a number of countries, and financing the costs of these actions, as well as the costs of the coordination mechanism itself, is an IPG. The fundamental disconnect between the requirements of the theory and Bank practice is that the Bank (IBRD or IDA) enters into loan agreements with individual countries, while what is clearly needed, if the loan route is to be pursued, are creative mechanisms whereby a number of countries can jointly be made a loan. This expansion of the scope of Bank lending is the first implication of the reasoning developed in this paper.

To the extent that multi-country loans are difficult to develop and roll out because of structural impediments in a sovereign debt framework, this argues strongly for the development of grant instruments as a normal part of the Bank's country operations. There is of course a big debate about whether all of the Bank's operations, certainly in the poorest countries, should be on a grant basis. The practicality of financing coordination mechanisms between adjacent developing countries adds its weight to the side of the debate arguing for conversion to grant instruments. Thus greater use of grants is the second set of operational implications of an IPG-focused look at the World Bank's operations.

The theoretical principle of subsidiarity states that it should ideally be regional level institutions, not a global institution like the World Bank that should be addressing cross-border spillovers between small numbers of adjacent countries. In the short term there is often a strong argument for continued or even strengthened World Bank involvement in these local level IPGs. But over the long term there should be a strengthening of regional institutions to deal with these issues, through transfer of knowledge and skills. To the extent that the World Bank's financial resources are used for this, they will be helping to supply IPGs indirectly. A similar argument can be made for strengthening sectoral organizations that are currently relatively weak but are needed on IPG issues - health and WHO is an obvious example. Thus a systematic programme of strengthening of regional and specific sectoral organizations is thus the third operational implication of our reasoning.

On basic research into tropical agriculture and tropical diseases, World Bank practice and IPG theory are quite closely aligned; there are spectacular successes in the past and promising avenues being pursued currently. An expansion of financial resources into these operations is strongly suggested. However, there is scope for reform of World Bank practice from a closer examination of theory and practice. First, given that for the foreseeable future the bulk of the Bank's operations will be country specific, there should be a systematic attempt to feed in the lessons of country practice into these global initiatives; and this would give a substantive strategic role to the Bank over and above its financial role. The details of this need to be worked out, of course, but the key is the word "systematic" - the use of new technology to collect and collate information through to global initiatives is something at which the Bank should excel.

But the experience of the various successful global initiatives highlights a second issue. In a number of cases the Bank played a central role as a catalyst, using its convening power, and then took a less central role in discussions while perhaps maintaining its financial role intact. This "entrepreneurial role" of the Bank has been useful in the past and should be maintained and strengthened. This requires a certain amount of "blue sky thinking" to identify problems and potential solutions, and to start down the road of global consensus building on the issue. An expanded fund for pursuing such innovative ideas on IPGs, perhaps through an expanded Development Grant Facility is thus the fourth operational implication of the arguments in this paper.

As noted in the previous section, the Bank spends significant resources on general social sci- 
ence research into the development process itself, and to dissemination of the findings of this research. The Bank as a whole no doubt has a huge base of experience to report on from its country operations. A systematic and independent collation of this information would be an IPG. Reform suggests itself first of all in developing mechanisms that will enable raw information to be accessed the world over. New technology holds out some hope in this regard, and the Bank is already moving in this direction. But there is the fundamental problem referred to in the previous two sections. Social science is not like natural science. It is contested terrain to a much greater extent. Moreover, the Bank as a whole cannot possibly be viewed as an independent arbiter of social science research. It is owned by the rich countries, and it has operational policies that need to be defended. These features mean that social science research done by the Bank itself cannot fully lay claim to the mantle of an IPG. The issue is sharply seen in much of the "cross-country regression analysis" that is done at the Bank. Whatever one's views on the quality of this research, there is weak comparative advantage justification for this type of research to be done at the Bank - it does not rely on information peculiarly available to the Bank because of its country operations, nor on methods and techniques that are peculiar to the Bank. The fifth and final implication of the reasoning in this paper is that more of the research at the Bank should be farmed out to Universities and transparently independent institutions, where at least perceived independence will enhance its value as an IPG.

\section{Conclusion}

To summarize, the arguments in this paper have (at least) five implications for the operations of the World Bank. First, the development of multi-country loan instruments. Second, a stronger move in the direction of grant instruments, which will mean an increased charge on net income. Third, the use of grants to support build-up of key regional and sectoral organizations. Fourth, an increased use of grants to support basic research initiatives, and innovative development of new IPGs, through an expansion of the Development Grant Facility. Fifth, a greater farming out of social science research to independent institutions.

This paper has only begun the systematic and detailed investigation of international aid agencies as suppliers of IPGs. It has focused on the World
Bank, but many other agencies - the IMF and various UN specialized agencies, in particular - can and should be subjected to the same scrutiny. The details of the practice will differ in each case, of course, as will the application of the theory of IPGs in each case. Such analysis will contribute to an overall sense of what resource reallocation is needed in international agencies to address undersupply of IPGs. At the same time, it will highlight overlaps and duplications in the supply of IPGs. All international agencies are claiming their activities are essential as providers of IPGs, and they cannot all be right.

But the case of the World Bank itself, as the biggest aid agency of all needs more detailed analysis than has been possible here. We have used broad budget headings to characterize country specific operations and different types of multi-country operations that could be interpreted, or have been claimed by the Bank to be, IPGs. With the availability or more detailed budgets - more detailed than those available publicly in the Annual Reports - a more careful accounting would be possible to sort out items under country operations that should be reclassified to country specific operations and vice versa. While this may not lead to a big change in the overall proportions, it is an exercise worth doing. A concomitant of this exercise, however, would be a much more detailed set of operational and resource reallocation implications than the general ones developed here. For example, the overall set of activities currently lumped under Networks, Development Economics and World Bank Institute need to be examined against the criteria of IPGs. A more fine-grained conclusion on the research budget could then be reached.

There is, finally, a "big" question that we have left untouched. This is the issue of the World Bank (or the IMF) as an IPG per se. The IDA part of the Bank, for example, coordinates and acts as the channel for aid flows whose origins are not the Bank's own borrowing or its net income, but flows from donor countries that they have chosen to send through this mechanism rather than through direct bilateral arrangements. It is argued that in this sense IDA provides the IPG and, it is argued by some, because of this mechanism aid flows are greater than they otherwise would be, and hence developing countries benefit as well. This is a different argument from multi-country activities that IDA funds could support, or the positive externality that country specific use of IDA funds generates as the country in question develops and grows. Rather, it is that this mechanism for country specific programmes is bet- 
ter than others, better specifically than the alternative of all bilateral flows, and in providing this very mechanism the Bank provides an IPG. In the end, this may turn out to be the strongest IPG argument in favour of the World Bank.

\section{Notes}

1 JEL Classification: F0, H4, O1, O2.

2 The rising interest in the policy arena has led to an explosion of analytical work at the intersection of IPGs and development assistance: see, for example, Jayaraman and Kanbur (1999), Kanbur, Sandler and Morrison (1999), Kaul, Grunberg and Stern (1999), Sagasti and Bezanson (2001), Gerrard, Ferroni and Mody (2001), Arce and Sandler (2002) and Ferroni and Mody (2002).

3 There are a number of studies that set out the basic theory of public goods. See for example Cornes and Sandler (1996) or Sandler (1998) or Kanbur, Sandler and Morrison (1999).

4 There is of course a huge literature on aid effectiveness. Some recent examples include: Burnside and Dollar (2000), Tarp (2000) and Kanbur (2000).

5 There are a number of other theoretical considerations that will not be considered further in this paper. One example is how exactly actions in different countries contribute to the public good. These issues of the technology of public good provision are dealt with, for example, in Jayaraman and Kanbur (1999), Kanbur, Sandler and Morrison (1999) and Arce and Sandler (2002).

6 This is further discussed in Kanbur (2001).

7 The figures that follow are from the annual report of the World Bank (2001), Appendix 1, "World Bank Expenditures by Program Fiscal 1997-2001". The table can be downloaded from http://www.worldbank.org/ annualreport/2001/pdf/appendix.pdf.

8 Of course, this is a very rough and ready order of magnitude calculation. Sometimes under development Economics and World Bank Institute will support country operations, just as some times under Regions will support multi-country activities. A more sophisticated analysis can be conducted with more detailed budgetary data.

9 Other initiatives like the regional Water Initiative for Middle East and North Africa, http://lnweb18.worldbank. org/mna/mena.nsf/Sectors/MNSRE/AA7510D24 BEE223C85256B58005A5026?OpenDocument, are at the stage of seminars and meetings, with "normal" project activity projected some time into the future.

10 See Wilks (2001). For a discussion of the pressures on the World Bank from its major shareholder, see Wade (2002).

\section{References}

Arce M, Daniel G and Sandler T (2002). Regional Public Goods: Typologies, Provision, Financing and Development Assistance. Almkvist and Wiksell International, Stockholm.

Burnside C and Dollar D (2000). "Aid, Policies and Growth", American Economic Review, September, pp. 847-868.

Cornes R and Sandler T (1996). The Theory of Externalities, Public Goods and Club Goods, $2^{\text {nd }}$ Edition. Cambridge University Press, Cambridge.

Ferroni M and Mody A, eds. (2002). International Public Goods: Incentives, Measurement and Financing. Kluwer Academic Publishers, Norwell, MA.

Gerrard CD, Ferroni M and Mody A, eds. (2001). Global Public Policies and Programs: Implications for Financing and Evaluation. The World Bank, Washington DC.

Jayaraman R and Kanbur R (1999). "International Public Goods and the Case for Foreign Aid", in Kaul I, Grunberg I and Stern MA, eds., Global Public Goods: International Cooperation in the $21^{\text {st }}$ Century, pp. 418-435. Oxford University Press, New York.

Kanbur R, Sandler T and Morrison K (1999). The Future of Development Assistance: Common Pools and International Public Goods. Johns Hopkins Press for the Overseas Development Council, Washington DC.

Kanbur R (2000). "Aid, Conditionality and Debt in Africa", in Tarp F, ed., Foreign Aid and Development: Lessons Learnt and Directions for the Future, pp. 409-422. Routledge, London.

Kanbur R (2001). "Cross Border Externalities, International Public Goods and Their Implications for Aid Agencies", Cornell working paper http://aem.cornell.edu//research/ researchpdf/wp0103.pdf.

Kaul I, Grunberg I and Stern MA, eds. (1999). Global Public Goods: International Cooperation in the $21^{\text {st }}$ Century. Oxford University Press, New York.

Sagasti F and Bezanson K (2001). Financing and Providing Global Public Goods: Expectations and Prospects. Fritzes Kundservice, Stockholm.

Sandler T (1998). "Global and Regional Public Goods: A Prognosis for Collective Action”, Fiscal Studies, Vol. 19, No. 3, pp. 221-247.

Tarp F, ed. (2000). Foreign Aid and Development: Lessons Learnt and Directions for the Future. Routledge, London.

Wade R (2002). "US hegemony and the World Bank: The fight over people and ideas", Review of International Political Economy.

Wilks A (2001). "Development Through the Looking Glass: the World Bank in Cyberspace", Paper prepared for the $6^{\text {th }}$ Oxford Conference on Education and Development, Knowledge Values And Policy, September. http:// www.brettonwoodsproject.org.

World Bank (2001). Annual Report 2001, http://www. worldbank.org/annualreport/2001/wbar2001.htm. 


\section{G-24 Discussion Paper Series*}

Research papers for the Intergovernmental Group of Twenty-Four on International Monetary Affairs

No. 18 September 2002 Ajit SINGH

No. 17 April 2002

No. 16 January 2002

No. 15 December 2001

No. 14 September 2001

No. 13 July 2001

No. 12 July 2001

No. 11 April 2001

No. 10 March 2001

No. 9 February 2001

No. 8 January 2001

No. 7 December 2000

No. 6 August 2000

No. 5 June 2000

No. 4 June 2000

No. 3 May 2000

No. 2 May 2000

No. 1 March 2000
F. LÓPEZ-DE-SILANES

Gerardo ESQUIVEL and

Felipe LARRAÍN B.

Peter EVANS and Martha FINNEMORE

Charles WYPLOSZ

José Antonio OCAMPO

Yung Chul PARK and Yunjong WANG

Aziz Ali MOHAMMED

JOMO K.S.

Gordon H. HANSON

Ilan GOLDFAJN and Gino OLIVARES

Andrew CORNFORD

Devesh KAPUR and Richard WEBB

Andrés VELASCO

Katharina PISTOR

Andrew CORNFORD

T. Ademola OYEJIDE

Arvind PANAGARIYA
Competition and Competition Policy in Emerging Markets: International and Developmental Dimensions

The Politics of Legal Reform

The Impact of G-3 Exchange Rate Volatility on Developing Countries

Organizational Reform and the Expansion of the South's Voice at the Fund

How Risky is Financial Liberalization in the Developing Countries?

Recasting the International Financial Agenda

Reform of the International Financial System and Institutions in Light of the Asian Financial Crisis

The Future Role of the International Monetary Fund

Growth After the Asian Crisis: What Remains of the East Asian Model?

Should Countries Promote Foreign Direct Investment?

Can Flexible Exchange Rates Still "Work" in Financially Open Economies?

Commentary on the Financial Stability Forum's Report of the Working Group on Capital Flows

Governance-related Conditionalities of the International Financial Institutions

Exchange-rate Policies for Developing Countries: What Have We Learned? What Do We Still Not Know?

The Standardization of Law and Its Effect on Developing Economies

The Basle Committee's Proposals for Revised Capital Standards: Rationale, Design and Possible Incidence

Interests and Options of Developing and Leastdeveloped Countries in a New Round of Multilateral Trade Negotiations

The Millennium Round and Developing Countries: Negotiating Strategies and Areas of Benefits

\footnotetext{
* G-24 Discussion Paper Series are available on the website at: http://www.unctad.org. Copies of G-24 Discussion Paper Series may be obtained from the Publications Assistant, Macroeconomic and Development Policies Branch, Division on Globalization and Development Strategies, United Nations Conference on Trade and Development (UNCTAD), Palais des Nations, CH-1211 Geneva 10, Switzerland; E-mail: mdpb-ed.assistant@unctad.org.
} 